\title{
Coping or adapting? Experiences of food and nutrition insecurity in specialised fishing households in Komodo District, eastern Indonesia
}

\author{
Emily Gibson ${ }^{1 *}$ D, Natasha Stacey ${ }^{1}$, Terry C. H. Sunderland ${ }^{2,3}$ and Dedi S. Adhuri ${ }^{4}$
}

\begin{abstract}
Background: There is growing recognition of the need for fish to be better integrated into nutrition-sensitive strategies for addressing malnutrition. Fish are overwhelmingly produced by the small-scale sector, which supports food and nutrition security directly through the provision of fish and indirectly through the generation of income which can be used to purchase other desired foods. However, there has been relatively little research on the extent of food and nutrition security in specialised fishing communities. This study assessed food and nutrition security among households in specialised fishing communities in Komodo District, eastern Indonesia.

Methods: We assessed the seasonal nutrition quality of household diets using the Food Consumption Score for nutritional analysis and food insecurity using the Household Food Insecurity Access Scale in 66 households across three communities, using a modified cluster sampling strategy. We calculated and generated descriptive statistics for these indicators with Microsoft Excel and ran a logistic generalized linear mixed model to determine factors associated with severe food insecurity using SPSS. We used semi-structured interviews and focus group discussions to understand perceptions of, change over time, and strategies for dealing with food shortfalls.
\end{abstract}

Results: While most households have acceptable access to nutritious foods, especially protein and heme iron-rich foods, nearly one half of households consumed vitamin A rich foods on less than 3 days of the 7-day recall period in either season. More than half of households reported experiencing a moderate or severe level of food insecurity, with higher food insecurity in the wet season. Low maternal education (OR: 3.8, 95\% Cl 1.5-9.9) and lower household wealth (OR: $0.5,95 \% \mathrm{Cl} 0.3-0.9)$ were found to be associated with a severe level of food insecurity. Household's consumptive and non-consumptive response strategies reflect adaptation to chronic food insecurity but are nutritionally and economically unsustainable.

Conclusion: Households in specialised fishing communities in Komodo District consumed diets with low diversity and experienced high levels of food insecurity. There is a need for culturally-appropriate nutrition-sensitive strategies to enhance food and nutrition security in vulnerable fishing communities.

Keywords: Specialised fishers, Small-scale fisheries, Food and nutrition security, Dietary diversity, Indonesia

\footnotetext{
* Correspondence: emily.gibson@cdu.edu.au

'Research Institute for the Environment and Livelihoods, Charles Darwin

University, Ellengowan Drive, Darwin, Northern Territory, Australia

Full list of author information is available at the end of the article
}

(c) The Author(s). 2021 Open Access This article is licensed under a Creative Commons Attribution 4.0 International License, which permits use, sharing, adaptation, distribution and reproduction in any medium or format, as long as you give appropriate credit to the original author(s) and the source, provide a link to the Creative Commons licence, and indicate if changes were made. The images or other third party material in this article are included in the article's Creative Commons licence, unless indicated otherwise in a credit line to the material. If material is not included in the article's Creative Commons licence and your intended use is not permitted by statutory regulation or exceeds the permitted use, you will need to obtain permission directly from the copyright holder. To view a copy of this licence, visit http://creativecommons.org/licenses/by/4.0/ The Creative Commons Public Domain Dedication waiver (http://creativecommons.org/publicdomain/zero/1.0/) applies to the data made available in this article, unless otherwise stated in a credit line to the data. 


\section{Background}

Food insecurity is a pressing global issue and contributes to malnutrition in all its forms (undernutrition, micronutrient deficiency, and overweight and obesity) through the complex interplay of food and non-food factors that affect a person's nutritional status [39]. In 2018 an estimated 820 million people were classified as undernourished and two billion people were affected by micronutrient deficiency or 'hidden hunger' [40]. "Hidden hunger occurs when the quality of food people eat does not meet their nutrient requirements, so the food is deficient in micronutrients such as the vitamins and minerals that they need for their growth and development" [100]. Hidden hunger can occur in those consuming too little food or in those consuming too much energy-dense nutrient poor food. Globally, undernutrition was the underlying factor in $45 \%$ of all deaths of children under 5 years of age in 2011 [7], and suboptimal diets are responsible for more adult deaths than any other risks [44]. The most common nutritional deficiencies are of iron, zinc and vitamin A, and multiple micronutrient deficiencies can occur together in the same population [78]. The WHO [101] recommends consumption of a healthy diet to avoid nutritional deficiencies and non-communicable diseases. A healthy diet comprises an appropriate energy intake, increased intake of fruits, vegetables, legumes, nuts and wholegrains, moderate intake of animal-source foods such as fish, and reduced intake of ultra-processed foods, to meet the nutrient requirements of all age groups, including those with special nutrition needs, and is adapted to the local context and culture [77, 101, 104]. Ultra-processed foods "are typically high-energy-dense products, high in sugar, unhealthy fats and salt, and low in dietary fiber, protein, vitamins and minerals" ([76], p.1). They are generally manufactured in an industrial setting, and in developing countries are widely available as single-serve packaged sweet or savory snack foods. In the context of the multiple burden of malnutrition, and the complex challenges of a growing global population and climate change, there is growing recognition that healthy diets must also be produced by sustainable food systems so as to ensure food and nutrition security for present and future generations [36, 52, 54, 104].

Fish, and other edible marine resources (e.g. bêche-demer, octopus, sea shells, shrimp; hereafter "fish"), have largely been overlooked in discussions of food-based strategies to address malnutrition in the context of sustainable food systems $[10,53,62,63,68,91]$. Fish are a nutrient-dense animal-source food which provides 3.2 billion people with almost $20 \%$ of their average per capita intake of animal protein, with consumption higher in Indigenous fishing communities and small-island developing States [17, 22, 38]. However, the nutritional value of fish extends beyond protein, encompassing long-chain polyunsaturated fatty acids, micronutrients such as vitamins $\mathrm{A}, \mathrm{B} 12$ and $\mathrm{D}$, and minerals including calcium, phosphorous, iodine, zinc, bioavailable heme iron, and selenium [5, 11, 85]. Fish are an invaluable addition to plant-based diets because they enhance the bioavailability of non-heme iron and zinc from other foods consumed in the same meal $[69,70]$. In developing countries, the small-scale fisheries sector, operating across marine, inland and aquaculture systems, employs an estimated 33.1 million fishers on a full- or part-time basis, with an additional 2-3 people for every fisher employed in postharvest activities; half of these workers are women [72]. The sector provides a safety net function, with countless others engaged in fishing activity on an occasional and seasonal basis [6]. These activities contribute directly to food and nutrition security through the provision of fish for home consumption and indirectly through the generation of income which can be used to purchase other foods, including staples and lower-value fish, and to pay for other goods and services.

'Fish as food' is an important lens for thinking about the sustainability of fisheries and fishing communities [5, 63]. Studies at a global scale indicate that in some countries with a high malnutrition burden redirecting a small portion of marine finfish landings to local rather than export markets could have a meaningful impact on the nutritional value of local diets, especially for children under the age of five [51]. Studies at a local scale tend to focus on the apparent availability of fish, particularly in the context of marine governance and sustainability innovations, rather than on how fishing contributes to food and nutrition security within local fishing communities. Kawarazuka and Bene [58] mapped evidence of these contributions across three pathways (income, consumption and distribution), but noted that more research was required to quantify the linkages between fish-related livelihoods and nutrition. Moreover, fishing households face heightened risk of food insecurity as they are at risk of direct and trading entitlement failures because their food and nutrition security depends on the consumption of the food they produce (i.e. fish) and its sale to obtain other foods [14]. These risks may be higher in specialised fishing households and communities that are constrained by limitations of access to productive resources, infrastructure, economic and institutional capacity, and where the socio-cultural ties to fishing as a way of life are strong $[20,34,60]$.

In this paper, we present and analyze empirical data from a mixed methods exploratory case study of food and nutrition security in three specialised fishing communities in eastern Indonesia. We use food consumption frequency data to assess nutritional quality of diets at the household level, assess the prevalence and severity 
of food insecurity (access), and identify strategies used by households to manage during times of food insufficiency. The study contributes to the literature by identifying the vulnerability of specialised fishing households to chronic food insecurity and the need for crosssectoral nutrition-sensitive programmes to improve food security in similar communities in the tropical coastal seascape.

\section{Methods}

\section{Study area}

Indonesia has the largest reef-associated population in the world, with nearly one third of its' 270 millionstrong population living within $10 \mathrm{~km}$ of the coast [15, 105]. The country is the world's second largest producer of marine fish [38], with most of this catch harvested by small-scale fishers. Government data indicates that the majority of targeted commercial fish stocks are fully exploited or overexploited [74], and fisheries production is threatened by destructive and unsustainable fishing practices, land-based pollution, as well as climate variability $[4,15,18]$. Indonesia has demonstrated a highlevel political commitment to improving undernutrition, yet it is ranked 73rd out of 119 countries in the Global Hunger Index [95], the national prevalence of stunting in children under 5 years of age is 36.4 , and $28.8 \%$ of women of reproductive age are anaemic [102].

This research was undertaken in Komodo District, West Manggarai Regency, in the Province of Nusa Tenggara Timur (NTT). Fisheries are an important contributor to the local economy. Fishing and trading activity are dominated by Indigenous Sama-Bajau and Bugis households who live in settlements near the main fish landing site at Labuan Bajo and on numerous nearby islands. Fishing communities have slightly different fishing profiles, targeting different species using different gear, with a network of patrons and middlemen providing connections to local, domestic and even high-value export markets. While it is typically men who go to sea, women are involved in activities across the local value chain. However, women's involvement is predominantly in unpaid pre- and post-harvest activities that support their fisher spouse and extended family, or in seasonal post-harvest work for which they are remunerated with fish. The gendered division of labor reflects both Indigenous culture and Islamic religious observance.

In 2017, 20\% of the District's population were classed as poor [13]. A food security and vulnerability assessment conducted in 2015 by the Provincial government, in conjunction with the World Food Programme, considered Komodo District 'food secure' [46]; however only one third of households had access to electricity, 46\% had access to clean water and $49.31 \%$ of children under five had stunted growth [46]. A recent local study relying on food balance sheet data found that diets were lacking diversity [82].

Our case study sought to provide a holistic assessment of food and nutrition security in specialised fishing communities. Our research was guided by a comprehensive review of the literature and Kawarazuka and Bene's [58] pathways framework, which is in itself based on the UNICEF [93] 'determinants of nutritional status' (see Table S1). The three pathways (income, consumption and distribution) in which fish may contribute to food and nutrition security are mapped across the basic, underlying and immediate causes of nutritional status (or outcomes). We purposively selected three villages for our case study, each situated on a different island located between seven and $14 \mathrm{~km}$ from Labuan Bajo. There was a high prevalence of fishing livelihoods in each of the villages, but the villages differed based on their structure (formal / informal village status), geography (small rock outcrop to large savannah island, with/without fringing reef), population size, and location. The first component of our research (undertaken simultaneously) explored the contribution of fish to the diets of women of reproductive age and infants and young children [45]. We found that while fish was a central component of women's diets, over $50 \%$ of mother-child pairs failed to meet the minimum recommended dietary diversity. Furthermore, the introduction of fish to young children's complementary diets was delayed due to fears and other concerns. This paper assesses the extent of food and nutrition security at the household level and responses to food insecurity.

\section{Data collection}

The research applied mixed methods, with a combination of qualitative and quantitative research activities suited to an interdisciplinary exploration of food and nutrition security [30]. All field work was conducted between September 2017 and May 2018; research activities were conducted during five trips to each village, with activities sequenced to allow for comprehensive coverage of key thematic areas identified in the research framework as well as to allow for in-depth exploration of emerging themes (see Table 1) [25]. The extended field work period, and repetition of certain modules of the household questionnaire, also allowed for the development of familiarity and rapport between the research field team and community members [59]. This team comprised the first author and three locally-engaged research assistants who acted as facilitators for research activities and translators. Research assistants received training on key elements of the research framework and the data collection tools used. The household questionnaire and interview / discussion guides were prepared in advance and reviewed as part of the training to ensure 
Table 1 Summary of field site characteristics and research activities

\begin{tabular}{|c|c|c|c|c|c|}
\hline \multirow[t]{2}{*}{ Research activities } & \multicolumn{4}{|l|}{ Field sites } & \multirow[t]{2}{*}{ Total } \\
\hline & FS 1 & FS 2 & FS 3 & Labuan Bajo & \\
\hline Population / households ${ }^{a}$ & 1860 / 477 & $604 / 152$ & $242 / 56$ & & $2706 / 685$ \\
\hline Eligible households ${ }^{b}$ & 186 & 52 & 25 & & 263 \\
\hline \multicolumn{6}{|l|}{ Household survey } \\
\hline January 2018 & 36 & 20 & 10 & & 66 \\
\hline April 2018 & 34 & 15 & 10 & & $59^{c}$ \\
\hline \multicolumn{6}{|l|}{ Interviews } \\
\hline - Key informant & $5(3 \mathrm{M} ; 2 \mathrm{~W})$ & $3(2 \mathrm{M} ; 1 \mathrm{~W})$ & $2(1 \mathrm{M} ; 1 \mathrm{~W})$ & $6(2 M ; 4 W)$ & $16(8 \mathrm{M} ; 8 \mathrm{~W})$ \\
\hline - Semi-structured & $12(0 \mathrm{M} ; 12 \mathrm{~W})$ & $6(0 M ; 6 W)$ & $4(0 \mathrm{M} ; 4 \mathrm{~W})$ & $2(0 M ; 2 W)$ & $24(0 \mathrm{M} ; 24 \mathrm{~W})$ \\
\hline Focus group discussions & $5(8 M ; 29 W)$ & $2(4 \mathrm{M} ; 10 \mathrm{~W})$ & $2(6 \mathrm{M} ; 5 \mathrm{~W})$ & & 9 (18M; $44 \mathrm{~W})$ \\
\hline
\end{tabular}

$M$ man, $W$ woman

${ }^{a}$ estimate from village census information, October $2017 ;^{b}$ estimate based on information obtained from local health volunteers; ${ }^{c}$ participation in the second round of the household survey was reduced, with two households declining to participate and the remaining households absent from the village during the survey period

key concepts were accurately translated and that appropriate local terms were used. All activities were implemented in Indonesian or the local dialect (Bahasa Bajau), in which case one research assistant acted as a secondary translator.

The introduction to research activities included an explanation of the purpose of the study, and later a summary of activities undertaken to that point in time, and how the instant activity contributed to the inquiry. Semi-structed interviews and focus group discussions were conducted to gather information about historic and contemporary livelihood activities across seasons, women's household and community roles, historic and contemporary meal patterns, and experiences of food insecurity and coping/adapting strategies for times of food insufficiency. Semi-structured interviews were conducted with key informants from the Regency's food security and fisheries agency and health department, community health staff and village leaders, and with community members (women, men, and those involved in fisheries). Key informants were identified based on their role (e.g. community nurse/midwife) and they subsequently identified potential community participants based on topics of interest. Additional participants were identified through purposive (i.e. to ensure coverage of different fishing activities) and snowball sampling [29]. Interviews were conducted in the participant's home or office and lasted for 30-75 min. Focus group discussions were held with community members identified by key informants. An initial focus group discussion in each community exploring seasonal food insecurity comprised a mix of women and men, whereas subsequent groups were targeted depending on the topic and themes to be explored and were conducted separately with either women or men (e.g. 'mothers with young children', 'males (open age) who fish'). Focus group discussions were held in village meeting places and lasted for approximately 45 min. Interviews were recorded unless the participant declined $(n=2)$. The audio recording was subsequently transcribed and translated by a research assistant. In the case of interviews that were not recorded and focus group discussions, detailed notes were taken at the time of the activity and then reviewed collaboratively by the field research team to ensure that key themes, discussion points and contributed stories were accurately documented. This, together with debriefing of research activities with the research team, supported bracketing throughout the study [92]. Key informants with public health roles provided feedback on preliminary findings from the household questionnaire (see below). We applied the principle of saturation in assessing topic coverage, while multiple sequential research activities allowed for triangulation [29, 87].

A household survey using a structured questionnaire was conducted in each of the island villages. Eligible households were those with at least one women of reproductive age (aged 18 to 49 years, hereafter referred to as women or mothers) and a child aged between 6 months and 5 years of age. The questionnaire comprised three parts: (a) respondent and household socioeconomic data, including men's and women's incomegenerating livelihood activities, asset ownership, and estimated monthly income and food expenditure; (b) food and nutrition security, including the Food Consumption Score Nutritional Quality Analysis [96, 97] and Household Food Insecurity Access Scale (HFIAS) [24] (see Data analysis below), both of which have been validated as indicators of household food insecurity in different settings, including Indonesia [3, 23, 103]; and (c) household decision-making and health and nutrition knowledge. The questionnaire comprised a combination of standard modules (e.g. access to drinking water and 
sanitation, food and nutrition security indicators) which were locally-adapted through discussion with key informants in accordance with relevant guidance documents, together with questions relevant to the study. The questionnaire is available as Supplementary Material to Gibson et al. [45]. The full questionnaire was conducted in January 2018 during the wet season and part (b) was repeated with the same households in late April during the dry season. ${ }^{1}$ This repetition allowed for the capture of seasonal variations in access to, availability of and consumption of fish and other foods. In total, 66 households participated in the survey. The sample size was determined based on the estimated prevalence of child stunting for Komodo District (49.31\% [46]) and the estimated number of eligible households, sufficient to give a standard error of $12.5 \%$ at a $95 \%$ confidence interval [26]. A list of eligible households was prepared with the assistance of local health staff and, as Indonesian villages are administratively divided into sections (RTs), five randomly selected eligible households from each section were surveyed. The survey took between $45 \mathrm{~min}$ and 1.5 $\mathrm{h}$ to complete. The survey was piloted in a similar mainland community and minor amendments were made to simplify rating scale questions.

\section{Data analysis}

\section{Food consumption score nutritional quality analysis}

Data on household food consumption was collected based on the module developed by [96, 97]). The module was pre-adapted using information about contemporary dietary patterns collected in key informant interviews, focus group discussions and a market survey of locally available foods. Additional questions were included about the type of fish consumed. A list method, in which the respondent is asked if anyone in her household has consumed foods from a particular food group in the preceding 7 days, and the number of days on which that food was consumed, followed by prompting about different meals and snacks and examples of locally-available foods, was used. The data were entered into a Microsoft Excel spreadsheet and the food consumption score was calculated following the prescribed method [96, 97]. Descriptive statistics for household food consumption score (poor $0 \leq 28$; borderline $28.5 \leq 42$; acceptable > 42 ), proportion of households consuming nutrientdense foods, and frequency of household consumption

\footnotetext{
${ }^{1}$ From the June to September, in the dry season (musim timur), the prevailing wind blows from the east, bringing little moisture and calmer seas conditions. From December to March, in the wet season (musim barat), the prevailing wind blows from the west, bringing higher rainfall and stormier weather. Transitional conditions occur in the remaining months. In 2018, the dry season was well established by early March.
}

of nutrient-dense foods were calculated. The threshold for an acceptable household diet was adjusted upwards as recommended by [96, 97]), given frequent consumption of sugar and oil. Frequency of consumption data are disaggregated as $0,1-3,4-6$ and 7 days (rather than the recommended $0,1-6$ and 7 days) because a high proportion of foods, especially vitamin A rich foods and fruits and vegetables, were reported to be consumed on only 1-3 days of the recall period. While 'fruits and vegetables' are not a specific category in the methodology, we present this data to gain a better understanding of consumption of nutrient-dense foods.

\section{Household food insecurity access scale}

Data on household experiences of food insecurity within the access domain of food security was collected using the module developed by Coates et al. [24]. The module comprises nine condition questions across three domains of food insecurity ((i) anxiety and uncertainty; (ii) insufficient quality; (iii) insufficient food intake and its physical consequences) and asks the respondent about the household's experience over the last 4 weeks. For each affirmative response, the respondent is asked about the frequency of occurrence of that experience, captured as rarely (1-2 times in the past 4 weeks), sometimes (310 times), often (> 10 times). The data were entered into a Microsoft Excel spreadsheet and descriptive statistics for the proportion of households experiencing each condition and domain, HFIAS score (range 0-27), and HFIAS prevalence (food secure, mildly, moderately and severely food insecure) were calculated following the prescribed method [24]. A food secure household experiences none of the food insecurity (access) conditions, or may just experience worry, but rarely; where as a severely food insecure household experiences a reduced quantity of food often, and/or experiences any of the most severe conditions, such as running out of food.

\section{Household wealth}

Household wealth was evaluated using a Material Styles of Life scale based on the building materials of the house, access to electricity (none, purchased, own source), access to improved sanitation, and the presence or absence of household assets (fan, television, mobile phone, tablet, fridge, couch/sofa set, washing machine, scooter) $[42,80]$. These items were factor analyzed using the principal component method, and items with low factor loadings removed [21]. The first principal component axis explained $27.72 \%$ of the variation in wealth among households. Households with higher wealth had homes with brick walls and cement floors, their own source of electricity and access to improved sanitation. 
The scale was weighted by the number of household members and households were grouped into three wealth levels: low (lowest 40\%), middle, and high (highest 20\%).

Additional analyses were undertaken in SPSS (version 24, IBM). Seasonal differences between mean household food consumption and HFIAS score were explored with paired t-tests. Seasonal differences between the proportion of households in each food consumption score and HFIAS category were explored using Wilcoxon signedrank tests. Seasonal differences between the frequency of consumption of key food groups and of foods within these food groups were explored using Wilcoxon signedrank and sign tests. Differences between household's experience of the HFIAS domains and conditions were explored using McNemar's tests. Logistic generalized linear mixed models (binomial with logit link, with household as a random intercept and variance component as covariance structure) were tested to assess the association between severely food insecure households and different socio-demographic factors, with a multivariable model developed with confounders and variables with $p<0.1$ from the univariable model included as predictors. Model diagnostics for the final multivariable model included a low Akaike Information Criterion and residual diagnostics, model convergence and absence of multicollinearity as indicated by variance inflation factors $(\mathrm{VIF}=1.0)$. Two-tailed $p$ values $<0.05$ were considered significant.

Transcripts of the interviews and focus group discussions, along with field notes, were entered into NVivo Pro 12 (QSR). Review and analysis of data occurred parallel to the extended period of field work, allowing for refinement and extension of research activities to explore emerging themes [81]. We applied content analysis to systematically analyze textual data and interpret its meaning [31]. The first author reviewed each data source numerous times to ensure familiarity and then coded the data deductively using an unconstrained categorization matrix based on themes (categories) and sub-themes drawn from the research framework [32] (see Supplementary Information: Table S1). Emergent sub-themes were added to the matrix as necessary. A structured approach was applied in which data were coded by sets of themes (i.e. multiple pass), data within categories was compared, then linkages between themes and sub-themes were evaluated [81]. This approach was appropriate given that the broader aim of the research project was to assess evidence of the contribution of fish and small-scale fishing livelihoods to food and nutrition security along Kawarazuka and Bene's [58] three pathways [32]. Anonymized representative participant quotes (identified by reference code) are provided to evidence perceptions of and responses to food insecurity [31].

\section{Results \\ Characteristics of households}

The average age of female respondents to the household survey was 29.7 years (SD +/- 6.7 years) (Table 2). Nearly half of the women $(48 \%)$ had not completed primary school, and $22.7 \%$ had attempted or completed a higher level of education. Households, comprising a collection of people who regularly eat together and sleep under the one roof [50], typically comprised between 4 and 6 members (59\% of all households) (excluding children who were boarding away from home). Larger households generally comprised a younger couple with children living with one set of parents, in which case the older female retained responsibility for management of household monies and food provision and preparation, with the younger couple contributing towards household expenses and labor.

The average number of income-generating livelihood activities per household was 2.24 ( $\mathrm{SD} \pm 1.08$; range 1-5), with $43 \%$ of households pursuing two or more incomegenerating livelihood activities. Men's livelihood strategies were centered on capture fishing and fish trading activities, with only $4.5 \%$ of households not engaged in small-scale fisheries activities. Men participated in ten different capture fisheries livelihood activities, with fishing practices varying according to the target species and gear used. Women in $41 \%$ of households reported pursuing an income-generating livelihood activity, typically home-based activities such as making and selling traditional cakes. Other women took up community roles such as volunteer health workers and received a small monthly incentive payment.

Approximately $17 \%$ of households were double burden households, with the mother classed as overweight or obese and an index child having stunted growth.

\section{Consumption of nutrient-dense foods}

Most households appear to have acceptable access to adequate food, with 89 and $97 \%$ of households having an 'acceptable' food consumption score for the wet and dry season respectively (wet season: $M=54.95, S D \pm 13.88$, range: $22.5-85$; dry season: $M=58.89, S D \pm 10.98$, range: 29-84). The mean food consumption score was higher in the dry season $(3.681,95 \%$ CI $[0.022,7.340])$. However, when the consumption frequency of nutrient-dense food groups is disaggregated, we found that most households consumed protein and iron rich foods every day, and vitamin A rich foods less frequently (Fig. 1). Protein-rich foods, principally fish, were consumed on all 7 days of the seven-day recall period by $86 \%$ of 
Table 2 Socio-demographic characteristics of female respondents and households

\begin{tabular}{|c|c|c|}
\hline Characteristics & Mean \pm SD or $n(\%)$ & $\mathbf{N}$ \\
\hline \multicolumn{3}{|l|}{ Maternal characteristics } \\
\hline Maternal age, years & $29.7 \pm 6.7$ & 66 \\
\hline Highest level of schooling completed & & 66 \\
\hline Some primary & $32(48.5)$ & \\
\hline Completed primary (6 years) & $19(28.8)$ & \\
\hline Some or completed secondary, or further education & $15(22.7)$ & \\
\hline Mother has income-generating livelihood activity & $26(39.4)$ & \\
\hline \multicolumn{3}{|l|}{ Household characteristics } \\
\hline Number of household members & $4.69 \pm 1.75$ & 66 \\
\hline Household livelihood activities (no.) & & 66 \\
\hline All livelihood activities & $2.24 \pm 1.08$ & \\
\hline Small-scale fisheries livelihood activities & $1.55 \pm 0.9$ & \\
\hline Women's livelihood activities & $0.45 \pm 0.41$ & \\
\hline Other non-fishing livelihood activities & $0.24 \pm 0.56$ & \\
\hline Material Styles of Life scale (wealth) & $\begin{array}{l}0, \pm 1 \\
\text { Range - } 1.21805,2.24643\end{array}$ & 66 \\
\hline Lowest wealth & $24(36.4)$ & \\
\hline Middle wealth & $30(45.5)$ & \\
\hline Highest wealth & $12(8.2)$ & \\
\hline Double burden households ${ }^{\text {a }}$ & $9(16.98)$ & 53 \\
\hline Recipient of RASTRA ${ }^{b}$ & $14(21.2)$ & 66 \\
\hline
\end{tabular}

households in the wet season and 98\% of households in the dry season (Fig. 2a). Consumption of heme iron rich foods was also frequent, with $82 \%$ of households consuming heme iron rich foods on all 7 days of the sevenday recall period in the wet season and 95\% of households in the dry season. Again, fish was the most important source of heme iron in household diets (Fig. 2b). Consumption of vitamin A rich foods was less frequent, with only 35 and $21 \%$ of households consuming vitamin A rich foods on all 7 days of the wet and dry season seven-day recall periods. Conversely, a higher proportion of households consumed vitamin A rich foods on only 1-3 days of the respective wet and dry season seven-day recall periods. The most commonly consumed vitamin A rich foods were eggs and dark green leafy vegetables (Fig. 2c). Consumption of vitamin A rich foods was likely higher in the wet season because eggs were used as a substitute when fish were not available and were provided to young children when only a non-preferred species of fish (e.g. squid) was available. Overall consumption of fruits and vegetables was very low in both the wet and dry seasons (Fig. 2d). Collectively, consumption of vitamin A rich foods $(z=-4.26, p<0.0005)$ and fruits and vegetables $(z=-2.27, p=0.023)$ were statistically significantly higher in the wet season.

\section{Perceptions of food insecurity experience}

Many of the households surveyed experienced varying degrees of food insecurity. Only 15 and 22\% of households were classed as food secure during the wet and dry seasons respectively (Fig. 3). Around one third of households were classed as severely food insecure in both seasons, with an additional third of households moderately food insecure in both seasons. Overall, reported experiences of food insecurity were higher in the wet season $(z=2.24, p=0.025)$.

A majority of households reported experiencing the domains 'anxiety and worry' about access to food (79\% wet season, $69 \%$ dry season), and an 'insufficient quality of food' (79\% wet season, $71 \%$ dry season) (Fig. 4). In interviews numerous women said they worried about securing food; for example, we often worry (IF9-FS1-2017); worrying about your children, whether they have something to eat or not (IF6-FS1-2017). The proportion of households that reported experiencing the different conditions of food insecurity was higher in the wet season. 


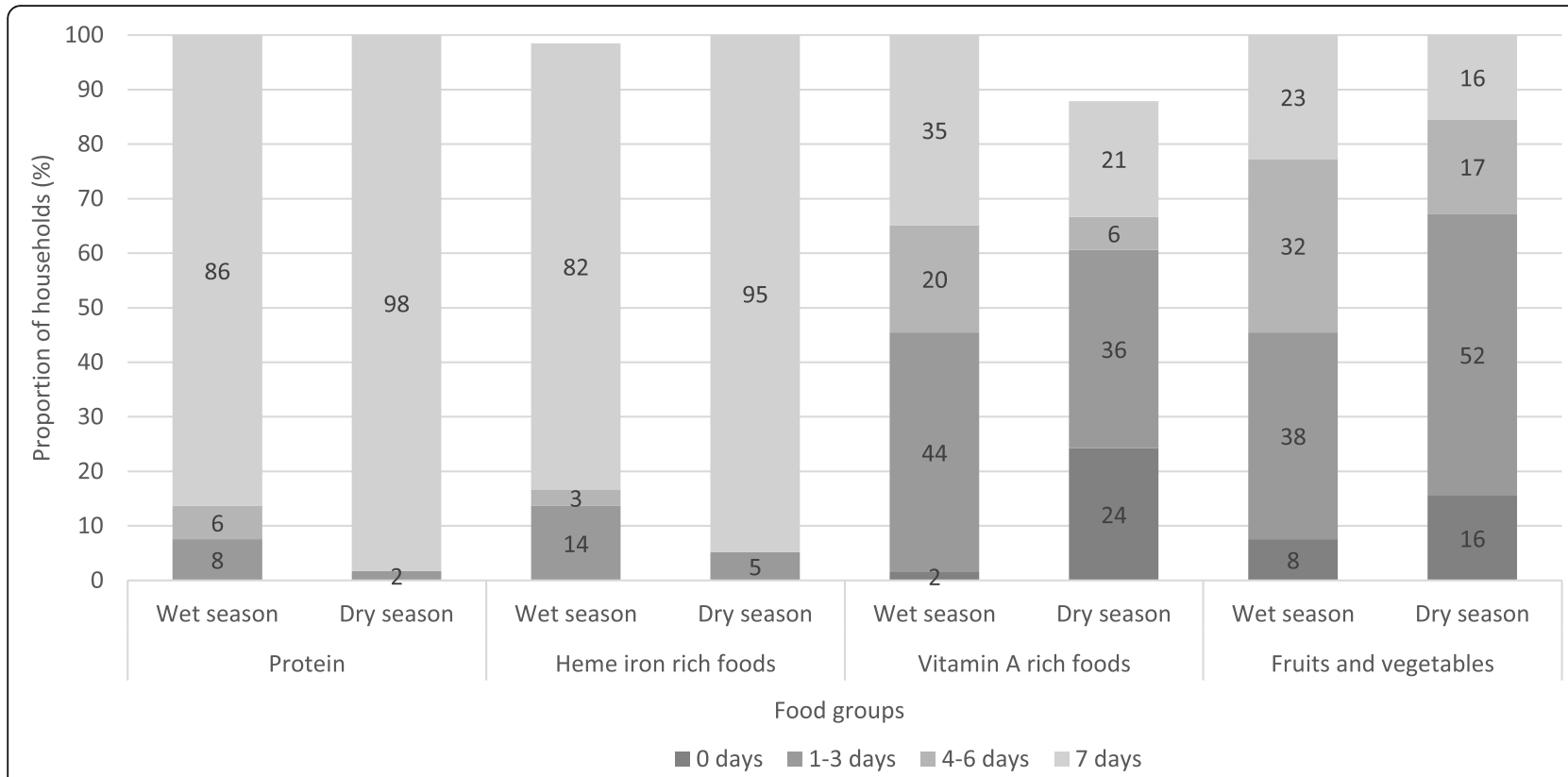

Fig. 1 Proportion of households consuming nutrient-rich food groups in 7-day recall periods, by frequency category. Figure 1 shows that most households were frequent consumers of protein and iron-rich food groups, and less frequent consumers of vitamin A rich foods, and fruits and vegetables

Overall, household perception of severity of experience of food insecurity was lower in the dry season, with a smaller proportion of households reporting experiencing the different conditions often (i.e. more than 10 times over the last 30 days). Reported frequency of experience of 'worry or anxiety' $(z=-3.39, p=0.0001)$, having to 'eat foods that really did not want to eat' $(z=-3.09, p=$ $0.002)$, 'eat fewer meals in one day' $(z=-2.19, p=$ 0.029 ), and having 'no foods of any kind in the household due to lack of resources' ( $z=-1.97, p=0.048$ ) were all significantly higher in the wet season.

\section{Factors affecting household perceptions of food insecurity experience}

The association between a household being severely food insecure and numerous independent variables was assessed: maternal characteristics (age, level of education, livelihood, mother having adequate dietary diversity), household characteristics (number household members, number livelihood activities, material style of life score, double burden household, household receives RASTRA), and season. The final model showed that the strongest predictors of households being severely food insecure were mother having low education (not having completed primary school) and households having a low MSL score (i.e. having low material wealth) (Table 3).

\section{Responses to food insufficiency}

Households employed a range of immediate and shortterm consumption strategies and longer-term non- consumption strategies in anticipation of or in response to a shortfall in food (Table 4). The primary consumption strategies employed were changes in diet and increasing short-term food supply. Women responded to a shortfall in food by purchasing cheaper and lesspreferred foods. As one woman from field site 1 explained: if there is no money, we eat noodles and eggs, because the fish here are expensive, the vegetables are also expensive (IF9-FS1-2018). In field site 2 some women buy dried cassava from a seller from Ende and alternate with rice in meals (FG1-FS2-2017); another woman explained: if [I] don't have rice, I grind down corn to make porridge or boil and mash banana (HSF4FS2-2017). Women also used their social capital to secure food from friends, neighbors and relatives; sharing of excess fish was common, and one woman revealed: yesterday my sister brought a large bowl of vegetable soup that had pumpkin and carrot in it and my family shared it (HSF1-FS2-2018). The purchasing of food on credit was also commonplace. Women obtained staple and other foods (e.g. flour, sugar) on credit from their husband's fishing boss, whom they described as stockpiling staples during the wet season, and other kiosk vendors. One third of households who had obtained loans from a boss had done so to secure food or meet other general household expenses. One woman explained: $m y$ ability is that if we have not enough money, I will try to owe the stall [and] I do selling cakes to cover our lack of money ... I will owe to someone; I don't care what people say, they don't know the situation (IF6-FS1-2017). The 


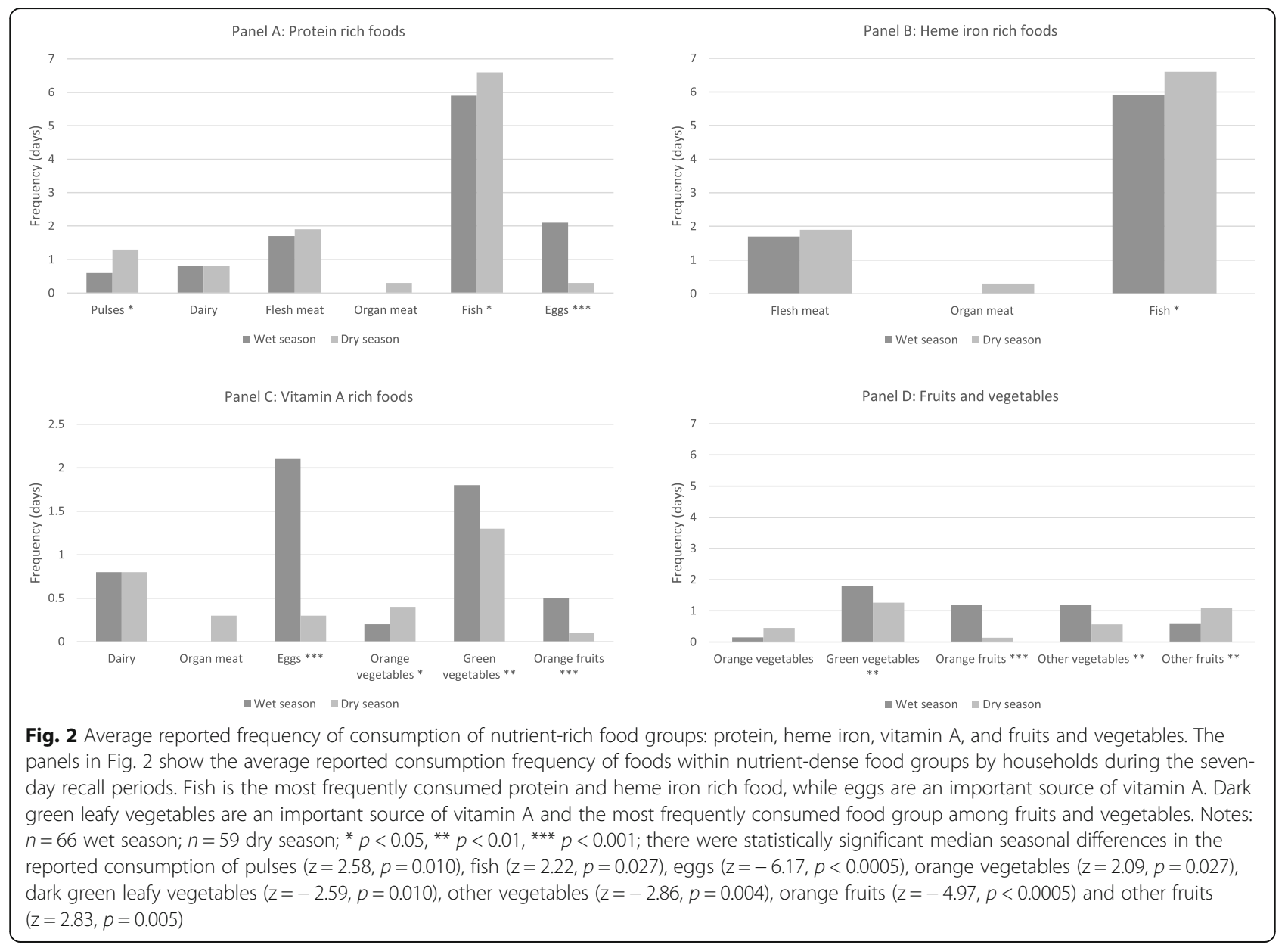

ability to obtain fruits and vegetables on credit from village vendors was identified by women as one of the reasons for not obtaining fruit and vegetables from the larger markets in Labuan Bajo. Resort to wild foods, such as gleaning for marine resources, was not common despite the maritime traditions of the Sama-Bajau. Women did occasionally harvest 'kelor' (Moringa oleifera) when they could not obtain other leafy greens: moringa leaves grow here so that would be our only vegetable [in the wet season] (IF4-FS1-2017). Overall, in times of food insufficiency women produced simpler less-nutritious meals comprising mainly rice or a substitute staple, with a small (or no) accompaniment. As one woman explained: sometimes [we] will just eat rice for a meal, when don't have fish or vegetables (HSF1-FS1-2017).

Households employed several non-consumption strategies. Fisher-husbands altered or re-directed their fishing practice while at sea depending on their success in harvesting higher-value export fish. If fishers had been unsuccessful, and hence had generated no income, they would re-direct their fishing effort to the harvest of small reef fish so as to ensure they were able to provide fish for their family. A fisher explained: the catch is uncertain, if the blessing is willing then I would have a lot of catch, but if the blessing is not willing, even for consumption would be hard to find (IM3-FS2-2018). Women also sought to increase their ability to access food by establishing home-based food or trading businesses. These small informal businesses were typically established with food stuffs or goods obtained on credit, and thus the women risked falling into debt. For example, one woman explained: I also sell some things which could be paid by installment... I see that as a business opportunity and then settle up the installment details ... the payment could be settled up to two or 3 years after my merchandise is sold ... I see a lot of people running the exact business as I do and I think I am the most patient creditor (IF2-FS1-2017). Around twofifths $(43.6 \%)$ of households kept free-roaming chickens or goats which could be sold for cash when required. Less than one third (29\%) of households accrued savings (in the form of cash or gold jewelry) 


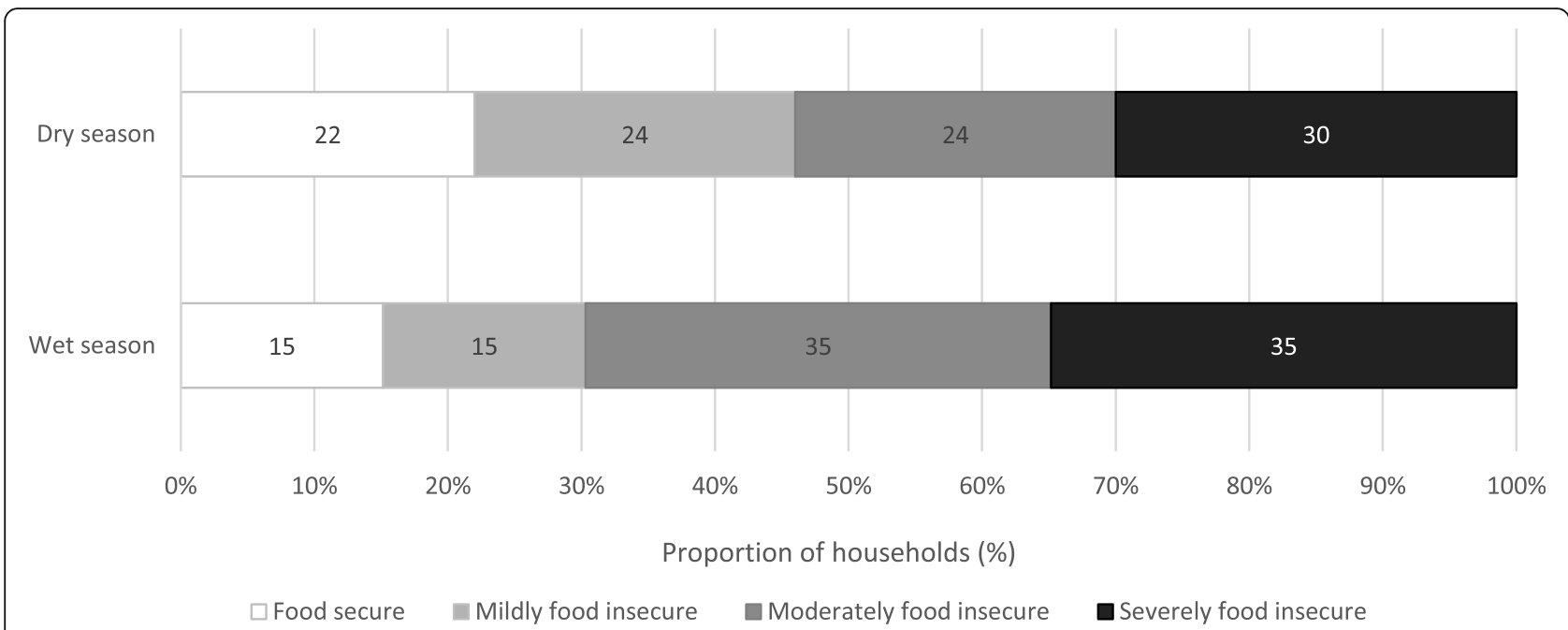

Fig. 3 Proportion of households experiencing food insecurity during the wet and dry seasons. Figure 3 shows the proportion of households experiencing the different degrees of food security, as determined by reported severity of experience of the different conditions

from their fishing and other business activities which could then be relied upon in times of food insufficiency.

\section{Discussion}

This study presents findings from an exploratory assessment of food and nutrition security in three specialised fishing communities in Komodo District, NTT, eastern Indonesia. We found that households appear at first to have adequate access to consumption of diverse food. However, the typical household dietary pattern comprised frequent consumption of the staple rice and regular consumption of fish, and only occasional consumption of vitamin A rich foods and fruits and vegetables in general. Fish were the primary dietary source of protein and heme iron; a wide range of fish were consumed, including reef-associated finfish such as emperor, rabbitfish and grouper, and small pelagics such as anchovy and sardines. Studies indicate that fish can be an important dietary source of vitamin A [11, 85]. However fish are not included in the 'vitamin A rich food group' used to construct the Food Consumption Score for nutritional quality analysis, perhaps reflecting the indicator's historical development in Sub-Saharan Africa where per capita fish consumption is among the lowest in the world [38]. The inclusion of fish is hampered by complexity arising due to the form, content and bioavailability of vitamin A differing among fish species and also affected by a range of ecological processes $[16,84]$. Despite recent efforts in other countries [11, 79, 83], there is limited nutritional data available for commonly consumed fish in Indonesia. The Food Composition Table for Indonesian lacks sufficient detail, listing only a handful of fish (for example 'anchovy', 'fish', 'fish, sea' and 'fish, tuna') and fish dishes, although over 870 species of bony fish are marketed [89, 99]. This lack of information, applying equally to other key micronutrients and minerals such as iron and zinc, is compounded by limited understanding of the impact of post-harvest handling and processing and cooking methods on the nutrition quality of fish. In the case study communities, fish were observed being processed using methods that raised food safety concerns, further highlighting the complex interplay of factors associated with ensuring access to adequate, nutritious and safe foods for all.

Household consumption of fruits and vegetables in the communities studied varied seasonally in accordance with local availability and corresponding affordability. A small number of nutrient-dense moringa trees (Moringa oleifera, kelor) were grown by individual households in each community. Moringa appear to be underutilized as a versatile and nutrient-dense food source, particularly given that little else was successfully cultivated locally. Fruits were considered as a snack food whereas vegetables were typically consumed in small portions as a side dish or incorporated sparingly in stir-fried dishes or soups. This appears consistent with other dietary patterns across Indonesia, with data at the national level indicating that Indonesians consume less than half the recommended daily amount of fruits and vegetables $[9$, 94]. Infrequent consumption of fruits and vegetables were also evident in the 24-h recall dietary quality data we collected for women of reproductive age and infants and young children [45]. Analysis of this data found that both the mother and child in one half of mother-child pairs surveyed had consumed fruits and vegetables in the 24 -h recall periods (53\% in the wet season and $49 \%$ in the dry season) and, that in $88 \%$ of mother-child pairs 


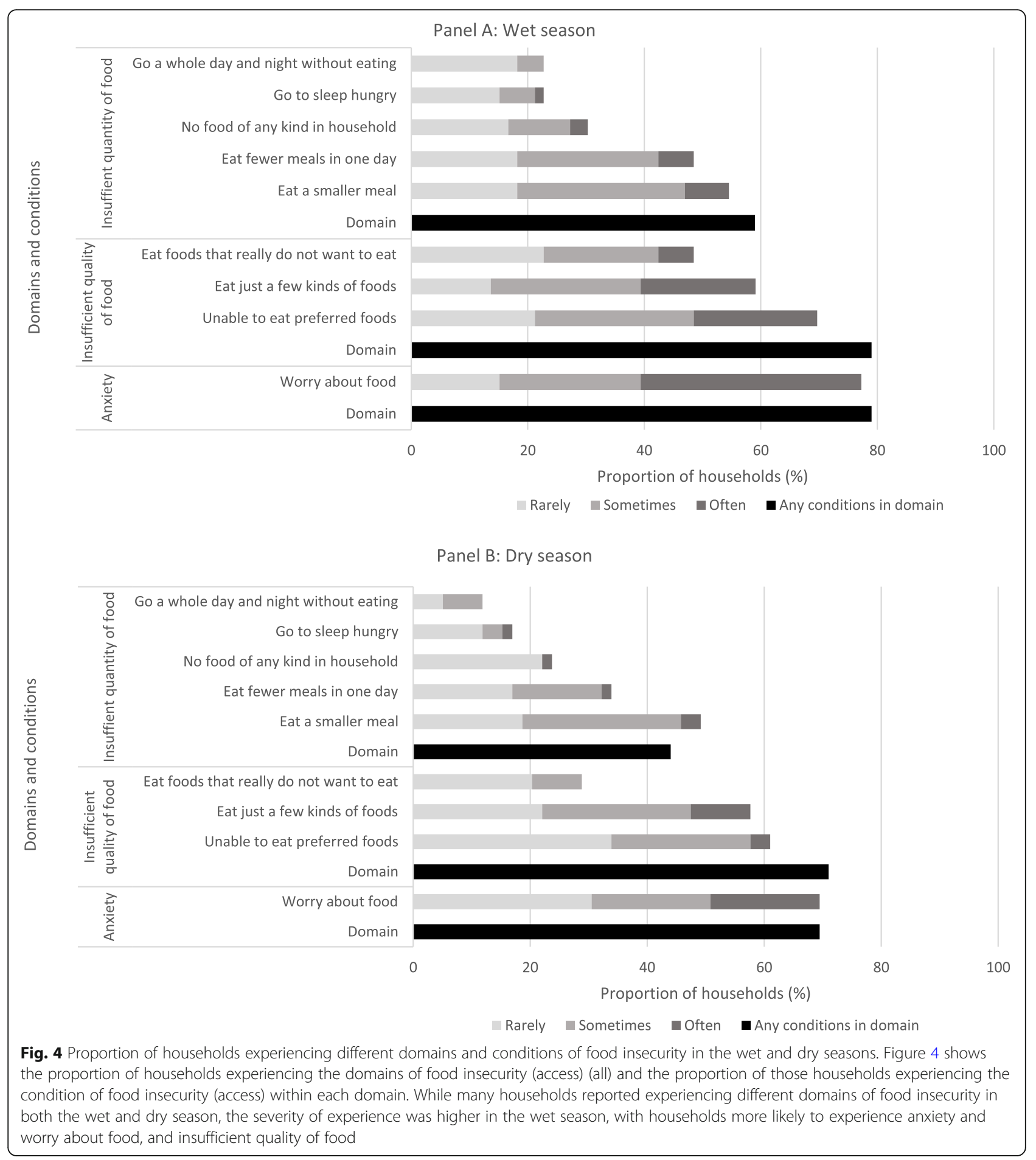

neither the mother nor child had consumed vitamin A rich fruits or vegetables. Other studies from Indonesia have shown that diets lacking diversity increase the risk of vitamin A and iron deficiency for infants and young children, female adolescents, and women of reproductive age, suggesting that women and children may be susceptible to micronutrient deficiencies despite the frequent consumption of fish $[8,64,86]$. Moreover, as is also observed in Albert et al. [1]'s study in the Solomon Islands, the dietary quality data contrast with the initial impression given by the Food Consumption Score. This suggests that the cutoff scores used for poor, borderline and acceptable diets in contexts where there is frequent consumption of fish (and other protein foods) should be 
adjusted further upwards. This anomaly reinforces the importance of selecting an appropriate combination of food and nutrition security indicators, depending on the purpose of the study and feasibility of data collection given available resources and other constraints [37, 61].

A healthy diet encompasses a balanced, diverse and appropriate selection of foods, ensuring that the need for macro- and micronutrients are met given a person's gender, age, physical activity level and physiological state [40]. Increasing dietary diversity is one of the core messages of Indonesia's revised dietary guidelines [75] and is included as an objective of the food-related policy framework (National Medium-Term Development Plan 2015-2019, Strategic Policy for Food and Nutrition 2015-2019, National Action Plan for Food and Nutrition 2017-2019). While recent progress has been made with respect to increasing the consumption of fish [2], consumption of fruits and vegetables declined by around 4 $\%$ between 2012 and 2016 and continues to fall, in line with dietary transitions occurring in many low- and middle-income countries [94]. There is a substantial difference in the frequency of consumption of fruits and vegetables between Indonesian households in the lowest and highest income quintiles [94]. A recent assessment found that 38\% of Indonesian households could not afford a staple-adjusted nutritious diet, increasing to $68 \%$ of households in NTT Province where nearly $60 \%$ of rural households' monthly expenditure is on food [12, 98]. Low levels of fruit and vegetable consumption have been reported in small island developing states across the Indo-Pacific region, largely due to cost and affordability but also changing taste preferences, convenience and environmental challenges [1, 19, 33, 57]. Availability and affordability are key factors influencing household purchasing decisions, with low income households tending to focus on consumption of sufficient energy-dense staple foods to meet calorie needs [88]. Efforts to increase dietary diversity are also influenced by taste preferences, food habits and taboos, low nutritional awareness, convenience, food safety concerns and changing lifestyles $[56,88]$. We also found that women served other members of their household before themselves and relied upon the advice of women elders and traditional midwives rather that community health personnel [45]. These factors can lead to inequalities in intrahousehold distribution of nutrient-dense foods, which can be masked by studies at the household level [49]. There is thus a critical need to further explore and address the barriers to consumption of nutrient-dense foods in the communities in this study area.

The households included in our study reported high levels of perceived food insecurity, with household perceptions of food security significantly higher in the dry season. Food insecurity was likely higher in the wet season due to poor weather conditions which kept fishers ashore resulting in there being less fish harvested for subsistence consumption or sold for income. Poor weather also meant that small fruit and vegetable vendors could not travel between the islands and mainland markets. Only a small proportion of households reported the more severe food insecurity condition experiences, such as 'not having food of any kind in the household' and 'going a whole day and night without eating', although these were rare occurrences. Fabinyi et al. [35] identified similar experiences in fishing communities in the Philippines. A higher level of food insecurity was associated with a low level of maternal education and lower material styles of life score, a proxy for household wealth. These factors have previously been identified as risk factors for food insecurity and children's micronutrient deficiencies $[48,90]$. Empowering women through education is argued to be the single most important determinant of food security, with women with higher levels of education likely to delay having children, have

Table 3 Association between a household being severely food insecure and explanatory factors

\begin{tabular}{|c|c|c|c|c|c|c|}
\hline \multirow[t]{2}{*}{ Factor } & \multicolumn{3}{|c|}{ Univariable model } & \multicolumn{3}{|c|}{ Multivariable model } \\
\hline & Odds ratio & $95 \% \mathrm{Cl}$ & $p$ value & Odds ratio & $95 \% \mathrm{Cl}$ & $p$ value \\
\hline Maternal age (years) & 0.9 & $0.9-1.0$ & & & & \\
\hline M hasn't completed primary school & 0.3 & $0.1-0.6$ & $0.005^{* *}$ & 3.8 & $1.5-9.9$ & $0.007^{* *}$ \\
\hline Mother has livelihood activity & 1.1 & $0.4-2.9$ & & & & \\
\hline Mother has adequate dietary diversity & 1.0 & $0.4-2.8$ & & & & \\
\hline No. household members & 1.1 & $0.8-1.5$ & & & & \\
\hline No. household livelihoods & 1.3 & $0.8-2.1$ & & & & \\
\hline Material Styles of Life score (scale) & 0.5 & $0.3-0.8$ & $0.011 *$ & 0.5 & $0.3-0.9$ & $0.020 *$ \\
\hline Double burden household & 0.5 & $0.1-2.7$ & & & & \\
\hline Household receives RASTRA & 3.3 & $1.1-10.0$ & $0.039 *$ & & & \\
\hline Season & 0.8 & $0.4-1.5$ & & & & \\
\hline
\end{tabular}

$\mathrm{Cl}$ Confidence Interval; $p$ value only shown when significant; ${ }^{*} p<0.05$ and ${ }^{* *} p<0.01$ 
Table 4 Strategies employed by households in response to food insufficiency

\begin{tabular}{ll}
\hline Type of strategy & Examples \\
\hline $\begin{array}{l}\text { Consumption strategies } \\
\text { Change diet }\end{array}$ & Consume cheaper / less-preferred foods, such as noodles and egg instead of preferred rice and fish \\
Increase short-term food supply & Borrow (or in kind) food from friends, neighbors or relatives \\
& Purchase food on credit from boss or kiosk owner \\
& Glean for marine resources \\
& Harvest locally-growing kelor (Moringa oleifera) \\
& Send children to relatives' homes for main meals \\
Reduce number of people to be fed & Reduce portion size for all family members \\
Ration food supplies & Reduce maternal portion size (eat only after other family members) \\
& Skip one or more meals in a day \\
& Fisher abandons income-earning fishing activity to ensure he harvests fish for household consumption \\
Non-consumption strategies & Female household member borrows money to establish a home-based food or trading business \\
Alteration of income-earning patterns & Sell small livestock (i.e. goats) \\
Sale of small assets & Sell or pawn gold jewelry \\
Use cash savings accrued during dry season
\end{tabular}

increased opportunity to participate in the work force, greater decision-making capability and the ability to influence household purchasing to support improved nutrition outcomes [55, 90]. Darling [27] and Fiorella et al. [43] found household wealth was associated with higher levels of food security in inland and coastal fishing communities in Kenya respectively, irrespective of the household pursuing fishing livelihoods.

In these specialised fishing communities, food insecurity was a cyclical and seasonal phenomenon, with the flow of fish, income and food linked to the type of fishing activity pursued. For many households, food insecurity reflected the lunar cycle, with night fishing practices such as spearfishing and lift-net fishing significantly reduced or ceasing during each full moon phase. Households employed a range of consumption and non-consumption strategies to manage through times of food insecurity; these include four commonly identified coping strategies: dietary change, foodseeking (including borrowing, purchasing on credit and reliance on wild foods), household structure, and rationing $[65,66]$. However the strategies were not "short-term responses to an immediate and inhabitual decline in access to food" [28], but rather routine insurance and adaptive strategies in response to the vagaries of the small-scale fisheries activities pursued and the broader socio-economic context. The income generated by fishing, particularly for poorer fishing households without fishing capital (boats, engines, gear), was too low to allow for savings, leaving the fisher and his household reliant on patron boat owners for work and other support such as loans to cover food or medical expenses [35, 41, 73]. While numerous studies have noted the importance of livelihood diversification strategies in increasing household resilience [47, 71], such options are limited in specialised fishing communities by the pervasiveness of patron-client relationships, geography, community size and cultural identity associated with fishing as a 'way of life' [67]. None of the households in the study communities engaged in cropping, kitchen gardens were uncommon, soils were poor and fresh water limited. Some fisher-wives created small food-based or petty-trade businesses, however, the vagaries of fishing and the flow of money within the communities impacted these businesses too, leaving the women vulnerable to debt. The range of strategies pursued by households highlights their high level of risk to entitlement failure, and vulnerability to continued food insecurity.

\section{Strengths and limitations}

This research places a spotlight on the experiences of food and nutrition security in remote rural specialised fishing communities, a vulnerable group which has been overshadowed by a consistent focus on food security in agricultural small-holder households. Several limitations should be considered. As a small crosssectional case study, the results relate to households in these communities comprising a woman of reproductive age and a child aged between 6 months and 5 years, and therefore may not be generalizable to the 
wider Indonesian population. The analysis drew on maternal-reported food consumption and experience of food insecurity data which may be subject to recall error and, despite careful explanation of the purpose of the study, social desirability bias. Consumption of fruits and vegetables are driven by seasonal availability and greater access due to lower prices. While we collected data in periods covering the major seasons from a fisheries perspective, neither survey period coincided with the local mango season which occurs from October to December. A repeat survey during that period may have produced elevated food consumption and dietary diversity scores due to more frequent consumption of mango, a vitamin A rich fruit. We acknowledge that the quality of food consumption data collected using questionnaires is imperfect and that quantitative dietary assessment with additional biochemical measures would allow for a more accurate assessment of nutrition status. Finally, research activities were undertaken by a multi-lingual field research team, so our methodology incorporated frequent cross-checking and the use of probing questions to clarify understanding and further explore responses. Transcripts were transcribed verbatim and checked for correspondence with contemporaneous notes, but unfortunately resources and timing did not allow for rechecking of transcribed material with research participants. While data were not co-coded, regular and reflexive debriefing supported bracketing.

\section{Conclusion}

This study assessed food and nutrition security in three specialised fishing communities in Komodo District, eastern Indonesia. We found that while households appeared to have access to diverse foods, and fish were important dietary sources of protein and heme iron, consumption of nutrient-dense fruits and vegetables was infrequent, leaving households vulnerable to micronutrient deficiency. We also found that households reported experiencing high levels of food insecurity, escalating in the wet season. Household members responded to shortfalls in food by employing a range of insurance and adaptive strategies, however these were nutritionally and economically unsustainable [28]. These findings highlight the vulnerability of specialised fishing communities, particularly given their linkages to international markets and the potential impacts of a changing climate. Enhancing food and nutrition security in specialised fishing communities requires a culturally-sensitive cross-sectoral response that strengthens livelihood opportunities, supports and/or provides improved financial literacy and affordable credit, and supports local production of higher-value fish-based foods and increased access to nutrient-dense fruits and vegetables.

\section{Supplementary Information}

The online version contains supplementary material available at https://doi. org/10.1186/s12889-021-10248-3

Additional file 1: Table S1. Outline of research framework, with themes and sub-themes used to code and analyse data.

\section{Abbreviations}

HFIAS: Household Food Insecurity Access Scale; NTT: Nusa Tenggara Timur: RT: Rukun tetangga (Bahasa Indonesia), neighborhood group

\section{Acknowledgements \\ We thank Neky Nitbani, Enggar Stitek and Apry Leokuna (research assistants), Mirjam Kaestli (Charles Darwin University), and each of the village leaders, community members and respondents from the study communities and associated area for their openness, hospitality and participation in research activities. We also thank the editors of BMC Public Health and three anonymous reviewers for their valuable feedback.}

\section{Authors' contributions}

EG: Conceptualization, Methodology, Investigation, Formal analysis, Writing original draft, Writing - review and editing; NS: Resources, Funding acquisition, Writing - review and editing; TS: Writing - review and editing; DA: Writing - review and editing. All authors read and approved the final manuscript.

\section{Funding}

EG was in receipt of an Australian Government Research Training Scholarship and received additional funding from Charles Darwin University and an ACIA R Small Research Activity. The funders played no role in study design, data collection and analysis, decision to publish or preparation of the manuscript. The research formed part of EG's doctoral thesis.

Availability of data and materials

The datasets used and/or analysed, and the interview and discussion guides used, during the current study are available from the corresponding author on reasonable request.

\section{Ethics approval and consent to participate}

This study was approved by the Human Research Ethics Committee at Charles Darwin University (H17085). The Indonesian Ministry of Research, Technology and Higher Education provided research clearance (247/SIP/FRP/ E5/Dit.KI/IX/2017), with additional permissions obtained from NTT Provincial and Regency officials and village leaders. All respondents provided written informed consent to participate in the study, which was recorded on survey questionnaires or interview and focus group discussion participant forms. Parental consents encompassed collection of their child's anthropometric data. The names of the case study villages are not disclosed in this paper to maintain community confidentiality.

\section{Consent for publication}

Not applicable.

\section{Competing interests}

The authors declare no competing interests.

\section{Author details}

${ }^{1}$ Research Institute for the Environment and Livelihoods, Charles Darwin University, Ellengowan Drive, Darwin, Northern Territory, Australia.

${ }^{2}$ Department of Forest and Conservation Sciences, University of British Colombia, 2424 Main Mall, Vancouver, Canada. ${ }^{3}$ Centre for International Forestry Research, Bogor, Indonesia. ${ }^{4}$ Research Centre for Society and Culture, Indonesia Institute of Sciences, JI.Jend Gatot Subroto 10, Jakarta, Indonesia. 


\section{Received: 15 July 2020 Accepted: 14 January 2021}

\section{Published online: 15 February 2021}

\section{References}

1. Albert J, Bogard JR, Siota F, McCarter J, Diatatlau S, Maelaua J, et al. Malnutrition in rural Solomon Islands: an analysis of the problem and its drivers. Matern Child Nutr. 2020;16(12):12. https://doi.org/10.1111/ mcn.12921.

2. Ambari M. The consumption of fish per capita is encouraged to reach 50 kilograms, how? (Konsumsi Makan Ikan Per Kapita Didorong Capai 50 Kilogram, Caranya Bagaimana?) Mongabay; 2018. https://www.mongabay. co.id/2018/01/23/konsumsi-makan-ikan-per-kapita-didorong-capai-50kilogram-caranya-bagaimana/. Accessed 22 Apr 2019.

3. Ashari C, Khomsan A, Baliwali Y. HFIAS validation in measuring food insecurity: case in urban and rural households in South Sulawesi. J Nutr Food Res. 2019;42(1):11-20. https://doi.org/10.22435/pgm.v42i1.2417.

4. Barange M, Merino G, Blanchard JL, Scholtens J, Harle J, Allison EH, et al. Impacts of climate change on marine ecosystem production in societies dependent on fisheries. Nat Clim Chang. 2014;4:211-6. https://doi.org/10. 1038/NCLIMATE2119.

5. Bene $C$, Barange $M$, Subasinghe $R$, Pinstrup-Andersen P, Merino G, Hemre $\mathrm{Gl}$, et al. Feeding 9 billion by 2050 - putting fish back on the menu. Food Security. 2015;7(2):261-74. https://doi.org/10.1007/s12571-015-0427-z.

6. Bene C, Hersoug B, Allison EH. Not by rent alone: analysing the pro-poor functions of small-scale fisheries in developing countries. Dev Policy Rev. 2010;28(3):325-58.

7. Black RE, Victora CG, Walker SP, Bhutta ZA, Christian P, de Onis M, et al. Maternal and child undernutrition and overweight in low-income and middle-income countries. Lancet. 2013;2013(382):427-51. https://doi.org/10. 1016/S0140-6736(13)60937-X.

8. Blaney S, Februhartanty J, Sukotjo S. Feeding practices among Indonesian children above 6 months of age: a literature review on their magnitude and quality (part 1). Asia Pac J Clin Nutr. 2015;24(1):16-27. https://doi.org/10. 6133/apjen.2015.24.1.13.

9. BMKG. Food security monitoring bulletin Indonesia: special focus: fruit and vegetables consumption and production trends. Jakarta; Government of Indonesia; 2017.

10. Bogard JR. Will fish be part future healthy and sustainable diets? Lancet Planet Health. 2019;3(4):e159-60.

11. Bogard JR, Thilsted SH, Marks GC, Wahab A, Hossain MAR, Jakobsen J, et al. Nutrient composition of important fish species in Bangladesh and potential contribution to recommended nutrient intakes. J Food Compos Anal. 2015; 42:120-33.

12. BPS - Statistics Indonesia. Consumption expenditure of population of Indonesia by province, based on the march 2016 SUSENAS. Jakarta; Government of Indonesia; 2016.

13. BPS West Manggarai Regency (2018). Manggarai Barat Regency in Figures, BPS Kabupaten Manggarai Barat.

14. Burchi F, De Muro P. From food availability to nutritional capabilities: advancing food security analysis. Food Policy. 2016;60:10-9.

15. Burke L, Reytar K, Spalding M, Perry A. Reefs at risk revisited in the coral triangle; 2012. p. 86.

16. Chakraborty K, Joseph D, Chakkalakal SJ, Vijayan KK. Inter annual and seasonal dynamics of amino acid, vitamin and mineral composition of Sardinella longiceps. J Food Nutr Res. 2013;1(6):145-55. https://doi.org/10. 12691/jfnr-1-6-6.

17. Charlton KE, Russell J, Gorman E, Hanich Q, Delisle A, Campbell B, et al. Fish, food security and health in Pacific Island countries and territories: a systematic literature review. BMC Public Health. 2016;16:26. https://doi.org/ 10.1186/s12889-016-2953-9.

18. Cheung WWL, Lam WY, Sarmiento JL, Kearney K, Watson R, Zeller D, et al. Large-scale redistribution of maximum fisheries catch potential in the global ocean under climate change. Glob Chang Biol. 2010;16:24-35. https://doi. org/10.1111/j.1365-2486.2009.01995.x.

19. Choy CC, Desai MM, Park JJ, Frame EA, Thompson AA, Naseri T, et al. Child, maternal and household-level correlates of nutritional status: a crosssectional study among young Samoan children. Public Health Nutr. 2017; 20(7):1235-47. https://doi.org/10.1017/S1368980016003499.

20. Cinner JE, Daw T, McClanahan TR. Socioeconomic factors that affect artisanal fishers' readiness to exit a declining fishery. Conserv Biol. 2009; 23(1):124-30. https://doi.org/10.1111/j.1523-1739.2008.01041.x.
21. Cinner JE, McClanahan TR, Wamukota A. Differences in livelihoods, socioeconomic characteristics, and knowledge about the sea between fishers and non-fishers living near and far from marine parks on the Kenyan coast. Mar Policy. 2010;34:22-8. https://doi.org/10.1016/j.marpol.2009.04.003.

22. Cisneros-Montemayor AM, Pauly D, Weatherdon LV, Ota Y. A global estimate of seafood consumption by coastal indigenous peoples. PLoS One. 2016;11(12):16.

23. Coates J, Frongillo EA, Rogers BL, Webb P, Wilde PE, Houser R. Commonalities in the experience of household food insecurity across cultures: what are measures missing. J Nutr. 2006;136(Supplement): 1438S-48S.

24. Coates J, Swindale A, Bilinsky P. Household food insecurity access scale (HFIAS) for measurement of household food access: indicator guide. 3rd ed. Washington, D.C.: FHI360/FANTA; 2007.

25. Creswell JW. Research design: qualitative, quantitative and mixed methods approaches. 3rd ed. USA: SAGE Publications; 2009.

26. Daniel WW, Cross CL. Biostatisics: a foundation for analysis in the health sciences. 10th ed. USA: Wiley; 2013.

27. Darling ES. Assessing the effect of marine reserves on household food security in Kenyan coral reef fishing communities. PLoS One. 2014;9(11): e113614. https://doi.org/10.1371/journal.pone.0113614.

28. Davies S. Are coping strategies a cop out? IDS Bull. 1993;24(4):60-72.

29. Denscombe M. The good research guide for small-scale social research projects. 2nd ed. Philadelphia: Open University Press; 2003.

30. Drimie S, McLachlan M. Food security in South Africa - first steps toward a transdisciplinary approach. Food Security. 2013;5:217-26. https://doi.org/10. 1007/s12571-013-0241-4

31. Elo S, Kaariainen M, Kanste O, Polkki T, Utriainen K, Kyngas H. Qualitative content analysis: a focus on trustworthiness. SAGE Open. 2014;2014:1-10. https://doi.org/10.1177/2158244014522633.

32. Elo $\mathrm{S}$, Kyngas $\mathrm{H}$. The qualitative content analysis process. J Adv Nurs. 2008 62(1):107-15. https://doi.org/10.1111/j.1365-2648.2007.04569.x.

33. Eme PE, Kim ND, Douwes J, Burlingame B, Foliaki S, Wham C. Are households in Kiribati nutrition secure? A case study of South Tarawa and Butaritari. Food Nutr Bull. 2020;16. https://doi.org/10.1177/ 0379572119891024

34. Fabinyi M. Food and water insecurity in specialised fishing communities: evidence from the Philippines. Nat Res Forum. 2018;42(4):243-53. https:// doi.org/10.1111/1477-8947.12148.

35. Fabinyi $M$, Dressler $W H$, Pido MD. Fish, trade and food security: moving beyond 'availability' discourse in marine conservation. Hum Ecol. 2016;45(2): 177-88. https://doi.org/10.1007/s10745-016-9874-1.

36. Fanzo J. Healthy and sustainable diets and food systems: the key to achieving sustainable development goal 2. Food Ethics. 2019;4:159-74. https://doi.org/10.1007/s41055-019-00052-6.

37. FAO. Compendium of indicators for nutrition-sensitive agriculture. Rome: FAO; 2016. p. 60.

38. FAO. The state of world fisheries and aquaculture 2018: meeting the sustainable development goals. Rome: FAO; 2018. p. 227.

39. FAO, IFAD, UNICEF, WFP, \& WHO. The state of food security and nutrition in the world 2018: building climate resilience for food security and nutrition. Rome: $F A O ; 2018$. p. 202

40. FAO, IFAD, UNICEF, WFP, \& WHO. The state of food security and nutrition in the world: safeguarding against economic slowdowns and downturns. Rome: FAO; 2019. p. 239

41. Ferrol-Schulte D, Ferse SCA, Glaser M. Patron-client relationships, livelihoods and natural resource management in tropical coastal communities. Ocean Coast Manag. 2014;100:63-73. https://doi.org/10.1016/j.ocecoaman.2014.07.016.

42. Filmer D, Pritchett LH. Estimating wealth effects without expenditute data or tears: an application to educational enrollments in states of India. Demography. 2001;38(1):115-32.

43. Fiorella KJ, Hickey MD, Salmen CR, Nagata JM, Mattah B, Magerenge R, et al. Fishing for food? Analyzing links between fishing livelihoods and food security around Lake Victoria, Kenya. Food Security. 2014;6:851-60. https:// doi.org/10.1007/s12571-014-0393-x.

44. GBD 2017 Diet Collaborators. Health effects of dietary risks in 195 countries, 1990-2017: a systematic analysis for the global burden of disease study 2017. Lancet. 2019;393:1958-72. https://doi.org/10.1016/S01406736(19)30041-8.

45. Gibson EC, Stacey N, Sunderland TCH, Adhuri DS. Dietary diversity and fish consumption by mothers and their children in fisher households in Komdo 
District, eastern Indonesia. PLoS One. 2020;15(4). https://doi.org/10.1371/ journal.pone.0230777.

46. Government of NTT Province, Food Security Council, Ministry of Agriculture, \& WFP (2015). Food Security and Vulnerability Atlas NTT 2015.

47. Hanazaki N, Berkes F, Seixas CS, Peroni N. Livelihood diversity, food security and resilience among the Caiçara of coastal Brazil. Hum Ecol. 2013;41(1): 153-64. https://doi.org/10.1007/s10745-012-9553-9.

48. Harding KL, Aguayo VM, Masters WA, Webb P. Education and micronutrient deficiencies: an ecological study exploring interactions between women's schooling and children's micronutrient status. BMC Public Health. 2018;470. https://doi.org/10.1186/s12889-018-5312-1.

49. Harris-Fry H, Shrestha N, Costello A, Saville NM. Determinants of intrahousehold food allocation between adults in South Asia - a systematic review. Int J Equity Health. 2017;16:21. https://doi.org/10.1186/s12939-017-0603-1.

50. Haviland WA. Cultural Anthropology, Belmont: California, Wadsworth/ Thompson Learning; 2002

51. Hicks CC, Cohen PJ, Graham NAJ, Nash KL, Allison EH, D'Lima C, et al. Harnessing global fisheries to tackle micronutrient deficiencies. Nature. 2019;574:95-8. https://doi.org/10.1038/s41586-019-1592-6.

52. HLPE. Food losses and waste in the context of sustainable food systems: a report by the High Level Panel of Experts on Food Security and Nutrition of the Committee on World Food Security. Rome: Commitee on World Food Security; 2014a. p. 117

53. HLPE. Sustainable fisheries and aquaculture for food security and nutrition: A report by the High Level Panel of Experts on Food Security and Nutrition of the Committee on World Food Security. Rome: Commitee on World Food Security; 2014b.

54. HLPE. Nutrition and food systems: a report by the High Level Panel of Experts on Food Security and Nutrition of the Committee on World Food Security. Rome: Commitee on World Food Security; 2017. p. 152.

55. UN Human Rights Council, Report submitted by the Special Rapporteur on the Right to Food: Women's rights and the right to food, 24 December 2012, A/HRC/22/50.

56. Ickowitz A, Rowland D, Powell B, Salim MA, Sunderland T. Forests, trees, and micronutrient-rich food consumption in Indonesia. PLoS One. 2016;11(5). https://doi.org/10.1371/journal.pone.0154139.

57. Jones HA, Charlton KE. A cross-sectional analysis of the cost and affordability of achieving recommended intakes on non-starchy fruits and vegetables in the capital of Vanuatu. BMC Public Health. 2015;15:10. https:// doi.org/10.1186/s12889-015-1644-2.

58. Kawarazuka N, Bene C. Linking small-scale fisheries and aquaculture to household nutrition security: an overview. Food Security. 2010;2:343-57.

59. Krefting L. Rigor in qualitative research: the assessment of trustworthinesS. Am J Occup Ther. 1991;45(3):214-22.

60. Lane D, Clarke CM, Forbes DL, Watson P. The gathering storm: managing adaptation to environmental change in coastal communities and small islands. Sustain Sci. 2013:8:469-89. https://doi.org/10.1007/s11625-013-0213-9.

61. Leroy JL, Ruel MT, Frongillo EA, Harris J, Ballard T. Measuring the food access dimension of food security: a critical review and mapping of indicators. Food Nutr Bull. 2015;36(2):167-95.

62. Lo M, Reed J, Costello L, Steel EA, Frimpong EA, Ickowitz A. The influence of forests of freshwater fish in the tropics: a systematic review. BioScience. 2020;70(5):404-14. https://doi.org/10.1093/biosci/biaa021.

63. Loring PA, Fazzino DV II, Agapito M, Chuenpagdee R, Gannon G, Isaacs M. Fish and food security in small-scale fisheries. In: Chuenpagdee R, Jentoft $S$, editors. Transdisciplinarity for small-scale fisheries governance: analysis and practice, MARE Publication Series, vol. 21. Cham: Springer International Publishing AG; 2019. p. 20

64. Madanijah S, Briawan D, Rimbawan R, Zulaikhah Z, Nandarwaulan N, Nuraida $L$, et al. Nutritional status of pre-pregnant and pregnant women residing in Bogor district, Indonesia: a cross-sectional dietary and nutrient intake study. Br J Nutr. 2016;116(S1):S57-66. https://doi.org/10.1017/ S000711451600057X.

65. Maxwell DG. Measuring food insecurity: the frequency and severity of "coping strategies". Food Policy. 1996;21(3):291-303.

66. Maxwell DG, Watkins B, Wheeler R, Collins G. The coping strategies index: field methods manual. Nairobi: CARE and the World Food Programme; 2003.

67. McGoodwin JR. Understanding the cultures of fishing communities: a key to fisheries management and food security. FAO Fisheries Technical Paper 401. Rome: FAO; 2001.
68. McIntyre PB, Reidy Liermann CA, Revenga C. Linking freshwater fishery management to global food security and biodiversity conservation. PNAS. 2016;113(45):6. https://doi.org/10.1073/pnas.1521540113.

69. Michaelsen KF, Hoppe C, Roos N, Kaestel P, Stougaard M, Lauritzen L, et al. Choice of foods and ingredients for moderately malnourished children 6 months to 5 years of age. Food Nutr Bull. 2009;30(3):S343-404.

70. Miller DD, Welch RM. Food system strategies for preventing micronutrient malnutrition. Food Policy. 2013;42:115-28. https://doi.org/10.1016/j.foodpol. 2013.06.008.

71. Mills DJ, Tilley A, Pereira M, Hellebrandt D, Pereira Fernandes A, Cohen PJ. Livelihood diversity and dynamism in Timor-Leste: insights for coastal resource governance and livelihood development. Mar Policy. 2017;82:20615. https://doi.org/10.1016/j.marpol.2017.04.021.

72. Mills DJ, Westlund L, de Graaf G, Kura Y, Willman R, Kelleher K. Underreported and undervalued: small-scale fisheries in the developing world. In: Pomeroy RS, Andrew NL, editors. Small-scale fisheries management: United Kingdom, CAB International; 2011. p. 1-15.

73. Minarro S, Forero GN, Reuter H, van Putten IE. The role of patron-client relationships on the fishing behaviour of artisanal fishermen in the Spermonde Archipelago (Indonesia). Mar Policy. 2016;69:73-83. https://doi. org/10.1016/j.marpol.2016.04.006

74. Minister of Marine Affairs and Fisheries (2017). Estimation of Potential Fish Resources in Fisheries Management Areas, Number 50/KEPMEN-KP/2017.

75. Ministry of Health. Guidelines for balanced nutrition. Jakarta: Government of Indonesia; 2014.

76. Monteiro CA, Cannon G, Levy RB, Moubarac JC, Louzada MLC, Rauber F, et al. Ultra-processed foods: what are they and how to identify them. Public Health Nutr. 2018;22(5):936-41. https://doi.org/10.1017/S1368980018003762.

77. Mozzaffarian D. Dietary and policy priorities for cardiovascular disease, diabetes, and obesity: a comprehensive review. Circulation. 2016;133:187225. https://doi.org/10.1161/CIRCULATIONAHA.115.018585.

78. Muthayya S, Rah JH, Sugimoto JD, Roos FF, Kraemer K, Black RE. The global hidden hunger indices and maps: an advocacy tool for action. PLoS One. 2013;8(6):12. https://doi.org/10.1371/journal.pone.0067860.

79. Nordhagen A, Rizwan AAM, Aakre I, Reksten AM, Pincus LM, Bokevoll A, et al. Nutrient composition of demersal, pelagic, and mesopelagic fish species sampled off the coast of Bangladesh and their potential contribution to food and nutrition security - the EAF-Nansen Programme. Foods. 2020;9:19. https://doi.org/10.3390/foods9060730.

80. Pollnac RB, Crawford BR. Assessing behavioural aspects of coastal resource use. In: Proyek Pesisir Publications Special Report. Rhode Island: University of Rhode Island: 2000. p. 139.

81. Pope C, Ziebland S, Mays N. Analysing qualitative data. Br Med J. 2000; 320(7227):114-6. https://doi.org/10.1136/bmj.320.7227.114.

82. Purnomo M. Ratio analysis of population to food needs in West Manggarai Regency (Analisis ratio jumlah penduduk terhadap kebutuhan pangan Kabupaten Manggarai Barat); 2017. p. 71.

83. Reksten AM, Somasundaram T, Kjellevold M, Nordhagen A, Bokevoll A, Pincus LM, et al. Nutrient composition of 19 fish species from Sri Lanka and potential contribution to food and nutrition security. J Food Compos Anal. 2020;91:13. https://doi.org/10.1016/j.fca.2020.103508.

84. Roos N, Leth T, Jakobsen J, Thilsted SH. High vitamin a content in some small indigenous fish species in Bangladesh: perspectives for food-based strategies to reduce vitamin a deficiency. Int J Food Sci Nutr. 2002;53(5): 425-37. https://doi.org/10.1080/0963748021000044778.

85. Roos N, Wahab A, Chamnan C, Thilsted ST. The role of fish in food-based strategies to combat vitamin a and mineral deficiencies in developing countries. J Nutr. 2007;137:1106-9.

86. Sandjaja S, Budiman B, Harahap H, Ernawati F, Soekatri M, Widodo Y, et al. Food consumption and nutritional and biochemical study of 0.5-12 year old Indonesian children: the SEANUTS study. Br J Nutr. 2013;110:S11-20. https:// doi.org/10.1017/S0007114513002109.

87. Saunders B, Sim J, Kingstone T, Baker S, Waterfield J, Bartlam B, et al. Saturation in qualitative research: exploring its conceptualization and operationalization. Qual Quant. 2017;52:1893-907. https://doi.org/10.1007/ s11135-017-0574-8.

88. Schreinemachers P, Simmons EB, Wopereis MCS. Tapping the economic and nutritional power of vegetables. Glob Food Sec. 2018;16:36-45. https:// doi.org/10.1016/j.gfs.2017.09.005.

89. SEAMEO, Ministry of Health, \& Wageningen University (2013). Food composition table for Indonesia, SMILING. 
90. Smith LC, Ramakrishnan U, Ndiaye A, Haddad L, Martorell R. The importance of women's status for child nutrition in developing countries: IFPRI; 2003. p. 178.

91. Thilsted SH, Thorne-Lyman A, Webb P, Bogard JR, Subasinghe R, Phillips $M$, et al. Sustaining healthy diets: the role of capture fisheries and aquaculture for improving nutrition in the post-2015 era. Food Policy. 2016;61:126-31.

92. Tufford L, Newman P. Bracketing in qualitative research. Qual Soc Work. 2012;11(1):80-96. https://doi.org/10.1177/1473325010368316.

93. UNICEF. Strategy for improved nutrition of children and women in developing countries. New York: UNICEF; 1990

94. Vermeulen S, Wllesley L, Airey S, Singh S, Agustina R, Izwardy D, et al. Healthy diets from sustainable production: Indonesia. London: Hoffman Centre for Sustainable Resource Economy; 2019. p. 48.

95. von Grebmer K, Bernstein J, Patterson F, Sonntag A, Klaus LM, Fahlbusch J, et al. 2018 global hunger index: force migration and hunger. Dublin \& Bonn: Welthungerhilfe and Concern Worldwide; 2018.

96. WFP. Food consumption analysis: calculation and use of the food consumption score in food security analysis. Rome: WFP; 2008. p. 24.

97. WFP. Food Consumption Score Nutritional Quality Analysis Guidelines (FCSN), Technical Guidance Note. Rome: Vulnerability and Assessment Mapping; 2015. p. 26.

98. WFP \& BAPPENAS. The cost of diet study in Indonesia. Jakarta: WFP; 2017. p. 69.

99. White MT, Last PR, Dharmadi FR, Chodrijah U, Prisantoso BI, et al. Market Fishes of Indonesia, vol. 155, ACIAR monographs. Canberra: ACIAR; 2013.

100. WHO (2014). What is hidden hunger? https:/wwww.who.int/nutrition/topics/ WHO_FAO_ICN2_videos_hiddenhunger/en/.

101. WHO (2018). Healthy diet. http://www.who.int/mediacentre/factsheets/fs3 94/en/.

102. WHO (2019). NLiS Country Profile: Indonesia.

103. Wiesmann D, Bassett L, Benson T, Hoddinott J. Validation of the world food Programme's food consumption score and alternative indicators of household food security, IFPRI Discussion Paper (no. 00870). Washington D. C.; 2009.

104. Willett W, Rockstrom J, Loken B, Springmann M, Lang T, Vermeulen S, et al. Food in the Anthropocene: the EAT-Lancet Commission on healthy diets from sustainable food systems. Lancet. 2019;393:447-92. https://doi.org/10. 1016/S0140-6736(18)31788-4.

105. World Bank. World development indicators: Development Research Group; 2020; http://data.worldbank.org/data-catalog/world-development-indicators. Accessed 31 Dec 2020.

\section{Publisher's Note}

Springer Nature remains neutral with regard to jurisdictional claims in published maps and institutional affiliations.

Ready to submit your research? Choose BMC and benefit from:

- fast, convenient online submission

- thorough peer review by experienced researchers in your field

- rapid publication on acceptance

- support for research data, including large and complex data types

- gold Open Access which fosters wider collaboration and increased citations

- maximum visibility for your research: over $100 \mathrm{M}$ website views per year

At $\mathrm{BMC}$, research is always in progress.

Learn more biomedcentral.com/submissions 